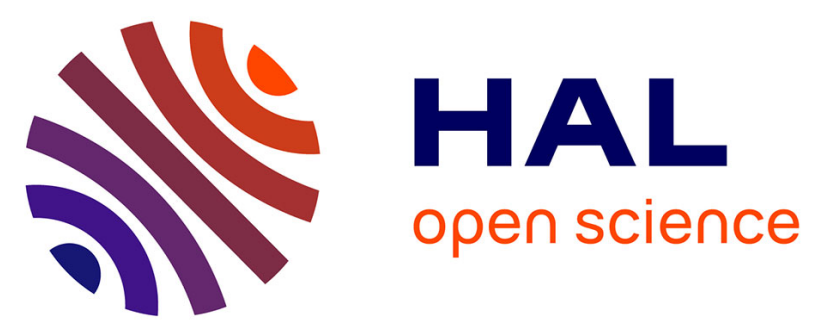

\title{
Culture conditions affect Lactobacillus reuteri DSM 17938 ability to perform glycerol bioconversion into 3-hydroxypropionic acid
}

Thi-Lan-Phuong Nguyen, Claire Saulou-Berion, Jérôme Delettre, Catherine Béal

\section{To cite this version:}

Thi-Lan-Phuong Nguyen, Claire Saulou-Berion, Jérôme Delettre, Catherine Béal. Culture conditions affect Lactobacillus reuteri DSM 17938 ability to perform glycerol bioconversion into 3hydroxypropionic acid. Journal of Bioscience and Bioengineering, 2021, Journal of Bioscience and Bioengineering, 131 (5), pp.501-508. 10.1016/j.jbiosc.2020.12.011 . hal-03162681

\section{HAL Id: hal-03162681}

\section{https://hal-agroparistech.archives-ouvertes.fr/hal-03162681}

Submitted on 8 Mar 2021

HAL is a multi-disciplinary open access archive for the deposit and dissemination of scientific research documents, whether they are published or not. The documents may come from teaching and research institutions in France or abroad, or from public or private research centers.
L'archive ouverte pluridisciplinaire HAL, est destinée au dépôt et à la diffusion de documents scientifiques de niveau recherche, publiés ou non, émanant des établissements d'enseignement et de recherche français ou étrangers, des laboratoires publics ou privés. 

9 yield

\section{Culture conditions affect Lactobacillus reuteri DSM 17938 ability}

to perform glycerol bioconversion into 3-hydroxypropionic acid

Thi-Lan-Phuong Nguyen, Claire Saulou-Bérion*, Jérôme Delettre, Catherine Béal

Université Paris-Saclay, AgroParisTech, INRAE, UMR 0782 SayFood, F-78850, Thiverval-

Grignon, France

\section{Keywords:}

Lactobacillus reuteri, Plackett and Burman experimental design, growth medium composition, environmental culture conditions, glycerol bioconversion, 3-hydroxypropionic acid production

\section{Abstract}

The platform molecule 3-hydroxypropionic acid (3-HP) can be produced using Lactobacillus reuteri through a two-step bioprocess that involves a growth phase followed by a bioconversion phase. The bioproduction is performed by resting cells that convert glycerol into 3-HP and 1,3propanediol in fed-batch mode. This work aimed at studying the effect of the growth conditions of L. reuteri DSM 17938 during the first step, on the glycerol bioconversion into 3-HP during the second step. A Plackett and Burman design was carried out to test, in controlled bioreactors, the effect of 11 growth conditions simultaneously, at fixed bioconversion conditions. The supplementation of the growth medium with vitamin B12 and cysteine displayed a negative effect on the 3-HP bioproduction. The addition of glucose, phytone peptone, Tween 80, 1,2propanediol and betaine in the growth medium, together with a low temperature and an optimal $\mathrm{pH}$ of 6.0 during the growth phase increased the bioconversion duration from $56 \mathrm{~h}$ to $89 \mathrm{~h}$ at a glycerol feeding rate of $0.5 \mathrm{~g} \cdot \mathrm{h}^{-1}$. A validating experiment displayed that the 3-HP titer, 3-HP

\footnotetext{
* Corresponding author: Claire Saulou-Bérion. E-mail: claire.saulou@agroparistech.fr; phone number: +33 130 8154 17; fax number: +33130815597
} 
production yield and 3-HP specific production rate were significantly improved by $25 \%, 150$ $\%$ and $61 \%$, respectively.

\section{Introduction}

Using microorganisms to produce valuable biomolecules from renewable resources has gained great interest in the two last decades due to limitation of fossil fuel resources and overwhelming environmental issues. In such context, the development of a biotechnological process to produce the platform chemical 3-hydroxypropionic acid (3-HP) is a key issue as this weak organic acid displays many applications. Firstly, it can be used as preservative in the food or feed industry $(1,2)$. But its major attraction comes from its bi-functionality, i.e. the presence of a carboxyl group and a $\beta$-hydroxyl group, which makes 3-HP the precursor of a large variety of chemicals for multipurpose applications. It thus serves as a versatile agent for chemical reactions such as dehydration, oxidation, reduction, cyclization or polymerization that lead to the formation of acrylic acid, malonic acid, 1,3-PDO, propiolactone, valuable homopolymers (poly 3-HP) or copolymers (containing 3-HP), respectively (3). This explains why it was ranked as one of the top value-added platform molecules to be produced from biomass by the US Department of Energy (4). Some chemical synthesis routes have been proposed to obtain 3-HP from acrylic acid, 3-propiolactone, 3-hydroxypropionitrile, allyl alcohol, vinyl acetate and 1,3-PDO (5). However, these processes display several drawbacks such as the use of expensive raw materials, the high costs for operating processes and associated environmental issues (3).

Nowadays, a better alternative to produce 3-HP is based on biotechnological processes, by employing either natural microbial producers or genetically modified organisms (GMO) working as cell factories, including GMOs that do not produce 3-HP naturally and microorganisms producing 3-HP but genetically modified to improve their performances. Detailed information about genetically modified microorganisms is available in recent reviews 
$(6,7)$. L. reuteri is an attractive candidate due to its safety characteristics, its probiotic properties and its anaerobic but aerotolerant attributes (8). In considering 3-HP bioproduction, L. reuteri is naturally capable of converting glycerol into 3-HP and 1,3-PDO in equimolar proportions, as it possesses all the enzymes of the metabolic pathway for 3-HP biosynthesis encoded by the pdu operon (9). It has the ability to synthesize vitamin B12 that is an essential co-factor for the first enzyme of the glycerol metabolism (10), but cannot use glycerol as a carbon source (11), which allows glycerol to be completely valorized into 3-HP and 1,3-PDO through the bioconversion pathway.

The 3-HP bioproduction has to be achieved through a two-step process, which includes a growth phase to produce a high cellular concentration and a second step to perform the glycerol bioconversion into 3-HP by resting cells (12). Glycerol is firstly converted to 3hydroxypropionaldehyde (3-HPA) by a vitamin-B12 dependent glycerol dehydratase. 3-HPA is then either converted to 1,3-PDO or 3-HP through parallel reductive and oxidative branches that maintain the redox balance between $\mathrm{NADH}$ and $\mathrm{NAD}^{+} .1,3-\mathrm{PDO}$ is obtained from $3-\mathrm{HPA}$ using the enzyme 1,3-propanediol oxidoreductase (13), while 3-HP is the product of three successive reactions using propionaldehyde dehydrogenase, phosphotransacylase and propionate kinase $(12,14)$. The conditions to be employed during the bioconversion step have been identified with the aim of increasing the 3-HP concentration and productivity. The use of fed-batch cultures with glycerol supply is required to prevent accumulation of the toxic intermediate 3-HPA, since the rate of 3-HPA formation is higher than that of its subsequent conversion (12). The maximum rate of glycerol supply to L. reuteri DSM 20016 has been determined at $0.75 \mathrm{~g} \cdot \mathrm{h}^{-1}$ to avoid 3-HPA accumulation (16). The use of micro-aerobiosis was recommended to improve the 3-HP bioproduction (17). Finally, the absence of glucose was shown to reduce 1,3-PDO production due to a redox cofactor imbalance (12) and to prevent the synthesis of undesirable fermentation products (i.e. lactic acid, ethanol, acetic acid, $\mathrm{CO}_{2}$ ). 
The influence of some conditions implemented during the growth step, prior to bioconversion, has been studied, in the vast majority of cases with the aim of improving the growth performances. By considering the nutritional requirements of L. reuteri, the influence of carbon and nitrogen sources has been determined. Different carbon sources have been used to trigger L. reuteri growth, such as glucose alone $(18,19)$, glucose plus fructose, saccharose (19), galactose, lactose, melibiose, raffinose, saccharose (20) and industrial wheat or sugar beet syrup by-products that contained glucose and fructose (21). From these studies, glucose was demonstrated as the better carbon source to maximize L. reuteri growth (21). The suggested concentrations of glucose were comprised between $20 \mathrm{~g} \cdot \mathrm{L}^{-1}(22)$ and $30 \mathrm{~g} \cdot \mathrm{L}^{-1}$ (21). As $L$. reuteri displays a heterofermentative metabolism, glucose is catabolized through two pathways (phosphoketolase (PK) and Embden-Meyerhof-Parnas (EMP) pathways) that operate simultaneously and lead to the production of lactic acid, acetic acid, ethanol, $\mathrm{CO}_{2}$ and energy (19).

The effects of various nitrogen sources have been established on L. reuteri cell growth. Yeast extracts and peptones are commonly used for growth of lactic acid bacteria due to their composition in amino acids and vitamins which meets cell needs. Yeast extract is the most common source employed in the published studies concerning L. reuteri $(21,23)$. In addition, phytone peptone, which is obtained from papaic digestion of soybean meal, displays an interesting composition with 18 of the 20 natural amino acids (asparagine and glutamine are absent) and is a cheaper nutrient source than yeast extract. Phytone peptone was demonstrated to lead to the highest cell concentration by comparison with other nitrogen sources such as peptones of animal origin, tryptone, proteose peptone, tryptic soy broth, yeast extract, and beef extract, in L. reuteri DSM 20016 (24) and other L. reuteri strains (PTA-4965, 23272, and 55730) (25).

The addition of the amino acid cysteine was also considered as this component is an essential growth factor of some lactobacilli (26). For L. reuteri DSM 20016 and SD 2112 strains, it was 
99

100

101

102

103

104

105

recommended at concentrations between $0.1 \mathrm{~g} \cdot \mathrm{L}^{-1}(24)$ to $0.5 \mathrm{~g} \cdot \mathrm{L}^{-1}(20)$. However, the addition of $2 \mathrm{~g} \cdot \mathrm{L}^{-1}$ cysteine in the culture medium was mentioned to decrease the production of vitamin B12 by L. reuteri JCM1112 by a factor 3 to 5 (10). This amino acid is also known as a potent reducing agent, thus displaying antioxidative properties that help the cells to cope with the oxidative stress encountered during the recovery and concentration steps, as demonstrated with

\section{L. fermentum (27).}

Tween 80 is a key growth factor in culture media for lactobacilli, as it brings unsaturated fatty acids that allow reducing intracellular energy consumption, thanks to the down-regulation of de novo fatty acid synthesis in membrane phospholipids (28). It is for instance present at a concentration of $1 \mathrm{~g} \cdot \mathrm{L}^{-1}$ in MRS medium $(12,29)$ or added to reach $5 \mathrm{~g} \cdot \mathrm{L}^{-1}(21)$.

Besides, the influence of some other components in the culture medium of lactobacilli has been investigated. Supplementation with vitamin B12 $\left(0.1 \mathrm{mg} \cdot \mathrm{L}^{-1}\right)$, as a mandatory cofactor for the first enzyme in the pdu pathway, although not influencing $L$. reuteri growth, positively impacts the 3-HP bioproduction (21). The addition of 1,2-propanediol (1,2-PDO) has been studied as it is involved in the activation of genes of the pdu pathway $(16,30)$. It was added at a concentration of $5 \mathrm{~g} \cdot \mathrm{L}^{-1}$ into $L$. reuteri DSM 20016 growth medium prior to glycerol conversion (14). Betaine is a methylated derivative of the amino acid glycine that acts as an osmolyte to help lactic acid bacteria counteract the osmotic shocks they face during the harvesting and concentration stages (31). By considering L. buchneri R1102, it was demonstrated that the combined supplementation with $2 \mathrm{mmol} \cdot \mathrm{L}^{-1}$ betaine and $0.1 \mathrm{~mol} \cdot \mathrm{L}^{-1} \mathrm{KCl}$ in the growth medium, together with a further addition of $0.6 \mathrm{~mol} \cdot \mathrm{L}^{-1} \mathrm{KCl}$ at the end of growth, led to intracellular accumulation of betaine and improved cell survival during freeze-drying. Formulating the environmental parameters (i.e. growth temperature, $\mathrm{pH}$ or the base used for $\mathrm{pH}$ control) to improve cell growth and further bioconversion is also challenging. The temperature for $L$. reuteri growth is generally established at $37{ }^{\circ} \mathrm{C}(18,24,32)$. However, the optimum temperature for growth may differ from that maximizing a given metabolic activity. 
For example, cultures of L. fermentum CRL 251 and Bifidobacterium longum CRL 849 implemented at $30{ }^{\circ} \mathrm{C}$ showed a slower growth but a stimulated alpha-galactosidase activity, in comparison to that observed at $37{ }^{\circ} \mathrm{C}$ (33). In order to reduce inhibitory effects of acidic conditions, the $\mathrm{pH}$ must be controlled during growth with an appropriate base solution. The optimal pH for L. reuteri growth is generally between 6.0 and 6.8 (34). Recently, different $\mathrm{pH}$ values between 3.7 and 6.7 were tested during batch cultures of L. reuteri DSM 12246 and the final biomass concentration was enhanced at $\mathrm{pH} 5.5$ (35). Finally, the use of two kinds of bases have been reported for $\mathrm{pH}$ control during $L$. reuteri growth phase: $\mathrm{NaOH}(36,37)$ and $\mathrm{NH}_{4} \mathrm{OH}$ $(12,38)$.

However, they have never been compared for bacterial growth or 3-HP bioproduction.

From this information, it can be seen that most previous works studied the effects of culture conditions on L reuteri growth but not on 3-HP bioproduction. They show that many culture conditions during the growth phase affect the growth performances of $L$. reuteri. However the effects of these culture conditions were scarcely investigated on cell ability to subsequently convert glycerol into 3-HP. In addition, the reported studies focus on a limited number of factors, thus making it difficult to define the optimal conditions by taking all of them into account. In such context, the present work aimed at quantifying the effects of relevant culture conditions on L. reuteri capacity to produce 3-HP during the subsequent glycerol bioconversion stage. As 11 factors were selected, a Plackett and Burman experimental design was retained as it allowed identifying the key factors that act on 3-HP bioproduction and quantifying their main effects, together with reducing the number of experiments. All experiments were performed in bioreactors in order to evaluate the effects of the factors in well-controlled conditions.

\title{
Material and methods
}

\author{
Bacterial strain
}


The strain L. reuteri DSM 17938 was obtained from BioGaia AB, Stockholm, Sweden. It was

stored at $-80{ }^{\circ} \mathrm{C}$ in cryotubes with glycerol $20 \%$ as cryoprotectant. The inoculum was prepared by cultivating the cells in MRS broth (Biokar Diagnostic, Beauvais, France) for 16 hours at 37 ${ }^{\circ} \mathrm{C}$ and $100 \mathrm{rpm}$ and then in MRS broth supplemented with glucose $20 \mathrm{~g} \cdot \mathrm{L}^{-1}$ (VWR BDH Prolabo, Leuven, Belgium) for 8 hours in the same conditions. Inoculation of the culture medium was performed at a concentration of $5.1 .10^{-6} \mathrm{~g}$ of cell dry weight (CDW) per liter $\left(\mathrm{gCDW} \cdot \mathrm{L}^{-1}\right)$, corresponding to $5.8 .10^{4} 10^{3}$ cells $\cdot \mathrm{mL}^{-1}$. The specific growth rate was calculated by plotting the natural logarithm of CDW against time.

\section{Culture and bioconversion media}

The reference culture medium used for bacterial growth was composed of MRS broth added with $20 \mathrm{~g} \cdot \mathrm{L}^{-1}$ glucose. In accordance with the experimental design, it was supplemented or not with the following components: glucose $50 \mathrm{~g} \cdot \mathrm{L}^{-1}$ (instead of $20 \mathrm{~g} \cdot \mathrm{L}^{-1}$ ), yeast extract $25 \mathrm{~g} \cdot \mathrm{L}^{-1}$ (Organotechnie S.A.S, La Courneuve, France), phytone peptone $25 \mathrm{~g} \cdot \mathrm{L}^{-1}$ (Merck KGaA, Darmstadt, Germany), Tween $804 \mathrm{~g} \cdot \mathrm{L}^{-1}$ (VWR), vitamin B12 $0.1 \mathrm{mg} \cdot \mathrm{L}^{-1}$ (Sigma-Aldrich, Saint Louis, MO, USA), 1,2-PDO $3 \mathrm{~g} \cdot \mathrm{L}^{-1}$ (Sigma-Aldrich), cysteine $1 \mathrm{~g} \cdot \mathrm{L}^{-1}$ (Sigma-Aldrich), betaine $0.234 \mathrm{~g} \cdot \mathrm{L}^{-1}$ (Sigma-Aldrich) together with $\mathrm{KCl} 7.455 \mathrm{~g} \cdot \mathrm{L}^{-1}$ (Prolabo, Fontenay-sousBois, France). All media were autoclaved at $110{ }^{\circ} \mathrm{C}$ for 20 minutes. Additional glucose was autoclaved separately to prevent its degradation due to the Maillard reaction (18).

The bioconversion medium was composed of sterile osmosis water into which a glycerol (Sigma-Aldrich) solution at $100 \mathrm{~g} \cdot \mathrm{L}^{-1}$ was added at a constant flow rate (29).

\section{Two-stage process for 3-HP production}

The two steps of 3-HP bioproduction were carried out in controlled bioreactors. Cell growth was conducted in batch mode in a 5-L Sartorius B bioreactor (Sartorius, Dourdan, France). The agitation rate was set at $100 \mathrm{rpm}$ thanks to two Rushton propellers. The temperature and $\mathrm{pH}$ during growth were defined according to the experimental design $\left(33\right.$ or $37^{\circ} \mathrm{C}$, pH 5.5 or 6.0$)$. The $\mathrm{pH}$ was controlled either with $\mathrm{NH}_{4} \mathrm{OH} 14.8 \mathrm{~mol} \cdot \mathrm{L}^{-1}$ (Sigma-Aldrich) or with $\mathrm{NaOH} 8.75$ 
$\mathrm{mol} \cdot \mathrm{L}^{-1}$ (VWR). The growth step was stopped when the cells reached stationary phase. Bacteria were harvested by centrifugation (Avanti ${ }^{\circledR} \mathrm{J}$-E centrifuge; Beckman Coulter, Fullerton, CA) at 6,200 $\mathrm{g}$ for $10 \mathrm{~min}$ at $4{ }^{\circ} \mathrm{C}$. Cell pellets were then suspended in the same volume of sterile osmosis water to reach about $26.7 \pm 9.5 \mathrm{~g} \mathrm{CDW} \cdot \mathrm{L}^{-1}$, corresponding to about $3.2 .10^{10} \pm 1.3 .10^{10}$ cells $\cdot \mathrm{mL}^{-1}$.

Bioconversion was achieved in a 2-L bioreactor (Sétric Génie Industriel, Toulouse, France) with an initial working volume of $0.8 \mathrm{~L}$. It was performed in fed-batch mode, defined by a constant glycerol feeding rate of $0.5 \mathrm{~g} \cdot \mathrm{h}^{-1}$ to avoid 3-HPA accumulation. The $\mathrm{pH}$ was controlled at 6.0 by addition of $\mathrm{NH}_{4} \mathrm{OH} 1.48 \mathrm{~mol} \cdot \mathrm{L}^{-1}$, the temperature was set at $37^{\circ} \mathrm{C}$ and the agitation rate was maintained at $100 \mathrm{rpm}$ with two Rushton propellers. Bioconversion was stopped when no more 3-HP was produced, which was evaluated by the stop of $\mathrm{NH}_{4} \mathrm{OH}$ consumption.

Evaluation of cell concentration and analysis of cell physiological state by flow cytometry

The bacterial cell concentration was determined indirectly by measuring optical density at 600 nm (OD 600$)$ (spectrophotometer UV-Vis Evolution ${ }^{\mathrm{TM}}$ 201, Fisher Scientific SAS, Illkirch, France). Then, bacterial concentrations expressed in CDW were obtained from $\mathrm{OD}_{600}$ values using the correlation: $\mathrm{CDW}=0.2639 \times \mathrm{OD}_{600}\left(\mathrm{R}^{2}=0.99\right)$.

The physiological state of bacterial cells was assessed by flow cytometry after double fluorescent staining with carboxyfluorescein diacetate (cFDA) and propidium iodide (PI) (39). The cFDA allowed assessing cellular enzymatic activity after internalization and cleavage by intracellular esterases, thus forming green fluorescent carboxyfluorescein (cF). Nucleic acid dye PI was used to characterize cells with damaged membranes, in which it formed a fluorescent DNA-complex. Samples were first diluted with McIlvaine buffer $\mathrm{pH} 7.3$ (0.2 $\mathrm{mol} \cdot \mathrm{L}^{-1}$ disodium dihydrogen phosphate $\left(\mathrm{J} . \mathrm{T}\right.$. Baker, Deventer, NL) and $0.1 \mathrm{~mol} \cdot \mathrm{L}^{-1}$ citric acid (Fisher Chemical, Elancourt, France)) to reach a cell concentration of $10^{6}$ cells $\cdot \mathrm{mL}^{-1}$. One milliliter of diluted sample was added simultaneously with $10 \mu \mathrm{L}$ cFDA (Chemchrom V8, 
201 Biomérieux, Marcy-l'Etoile, France) diluted at $100 \mathrm{~mL} \cdot \mathrm{L}^{-1}$ in acetone (Fisher Scientific,

202 Leicestershire, UK) and $10 \mu \mathrm{L}$ PI $\left(1 \mathrm{~g} \cdot \mathrm{L}^{-1}\right.$ in distilled water, Sigma-Aldrich $)$ before incubation 203 at $40{ }^{\circ} \mathrm{C}$ for 10 min. Flow cytometry analyses were performed with a BactiFlow cytometer 204 (Sysmex Partec, Roissy, France) equipped with the Flowmax software (Partec). Cell 205 fluorescence was measured at $530 \mathrm{~nm}$ for $\mathrm{cF}$ and $670 \mathrm{~nm}$ for PI after excitation by a 488-nm emitting laser. Cells emitting in green only $(530 \mathrm{~nm})$ were considered as viable, while cells emitting in red only $(670 \mathrm{~nm})$ were considered as dead. The data collected included cell concentrations (in cells $\left.\cdot \mathrm{mL}^{-1}\right)$ and percentages of viable and dead cells $(29,39)$.

Substrates used for growth (glucose) and bioconversion (glycerol) as well as growth products (lactic acid, ethanol and acetic acid) and bioconversion metabolites (3-HP, 1,3-PDO and 3HPA) were quantified by high-performance liquid chromatography (Waters Associates, Molsheim, France). Growth samples were diluted twice with trichloroacetic acid (SigmaAldrich) at $60 \mathrm{~g} \cdot \mathrm{L}^{-1}$, then centrifuged at $13,000 \mathrm{~g}$ for $10 \mathrm{~min}$ at $4{ }^{\circ} \mathrm{C}$ before filtration through a $0.22 \mu \mathrm{m}$ pore-size filter (Sartorius Stedim Biotech, Gottingen, Germany). Bioconversion samples were added with citric acid $5 \mathrm{~g} \cdot \mathrm{L}^{-1}$, centrifuged and filtered in the same conditions. For each sample, a volume of $20 \mu \mathrm{L}$ was injected (Waters 717 plus) in mobile phase $\left(\mathrm{H}_{2} \mathrm{SO}_{4}\right.$, Sigma-Aldrich) on a cation-exchange column Aminex HPX-87H (300 mm $\times 7.8 \mathrm{~mm}$, Biorad, Richmond, USA). Two sets of conditions including column temperature, $\mathrm{H}_{2} \mathrm{SO}_{4}$ concentration and flow rate of the mobile phase, were applied to separate the components properly (Table 1). 2489). Quantification was achieved using the Empower software (Waters Associates) with the help of external standards. All analyses were duplicated and concentrations are given in $g \cdot \mathrm{L}^{-1}$. 


\begin{tabular}{|c|c|c|}
\hline & Condition A & Condition B \\
\hline Temperature $\left({ }^{\circ} \mathrm{C}\right)$ & 35 & 60 \\
\hline $\begin{array}{l}\mathrm{H}_{2} \mathrm{SO}_{4} \text { concentration in mobile } \\
\text { phase }\left(\mathrm{mmol} \cdot \mathrm{L}^{-1}\right)\end{array}$ & 5 & 0.5 \\
\hline $\begin{array}{l}\text { Flow rate of mobile phase } \\
\left(\mathrm{mL} \cdot \mathrm{min}^{-1}\right)\end{array}$ & 0.6 & 0.4 \\
\hline $\begin{array}{l}\text { Compounds detected in growth } \\
\text { samples (and corresponding } \\
\text { retention times, in min) }\end{array}$ & $\begin{array}{l}\text { Glucose (9.3), lactic } \\
\text { acid (13.2), acetic acid } \\
(15.6), \text { ethanol (21.2) }\end{array}$ & \\
\hline $\begin{array}{l}\text { Compounds detected in } \\
\text { bioconversion samples (and } \\
\text { corresponding retention times, } \\
\text { in min) }\end{array}$ & $\begin{array}{l}\text { 3-HPA (14.9), 1,3- } \\
\text { PDO (17.5), acetic acid } \\
\text { (15.6), ethanol }(21.2) \\
\text { (the two latter remaining from } \\
\text { growth) }\end{array}$ & $\begin{array}{l}\text { Lactic acid (18.7, } \\
\text { remaining from growth), } \\
\text { 3-HP (19.7), glycerol } \\
(20.7)\end{array}$ \\
\hline
\end{tabular}

227 The carbon mass balance has been calculated during growth $\left(\mathrm{CMB}_{\mathrm{G}}\right.$, in $\left.\% \mathrm{~mol} \cdot \mathrm{mol}^{-1}\right)$ according to the central metabolism of L. reuteri via PK and EMP pathways and during bioconversion $\left(\mathrm{CMB}_{\mathrm{B}}\right.$, in $\left.\% \mathrm{~mol} \cdot \mathrm{mol}^{-1}\right)$, from the equations below:

$\mathrm{CMB}_{\mathrm{G}}=\left(3 . \mathrm{n}_{\text {Lactic acid }}+2 \cdot \mathrm{n}_{\text {Ethanol }}+2 \cdot \mathrm{n}_{\text {Acetic acid }}+\mathrm{n}_{\mathrm{CO}_{2}}+\mathrm{n}_{\mathrm{C}}\right.$ in Biomass $) / 6 . n_{\text {Glucose }}$

With $\mathrm{n}$ being the number of moles of consumed glucose (nGlucose) and glycerol (n $\mathrm{n}_{\text {Glycerol }}$ ), produced lactic acid (nLactic acid), ethanol (nEthanol), acetic acid (nAcetic acid), $\mathrm{CO}_{2}$ ( $\mathrm{nCO}_{2}$ (hypothesized to be equal to the number of moles of produced [ethanol + acetate])), carbon in cells produced during growth ( $\mathrm{n}_{\mathrm{C}}$ in Biomass), 3-HP ( $\left.\mathrm{n}_{3-\mathrm{HP}}\right), 1,3-\mathrm{PDO}\left(\mathrm{n}_{1,3-\mathrm{PDO}}\right)$ and 3-HPA $\left(\mathrm{n}_{3-}\right.$ HPA).

\section{Experimental design and statistical analyses}

A Plackett and Burman matrix (40) allowed creating an experimental design to test the effects of 11 medium components and culture conditions on growth and subsequent 3-HP bioproduction by L reuteri DSM 17938. The general form of the model is given as follows: 
$241 \quad \mathrm{Y}_{\mathrm{i}}=\mathrm{k}_{\mathrm{i}}+\sum \mathrm{ai}_{\mathrm{i}} \cdot \mathrm{Y}_{(+) \mathrm{i}}$

242 Where $\mathrm{Y}_{\mathrm{i}}$ is the response variable; $\mathrm{k}_{\mathrm{i}}$, the constant value of $\mathrm{Y}_{\mathrm{i}}$ when all 11 variables are at their

243 Minus levels; $a_{i}$, the linear coefficient of each variable to express the effect of the Plus level;

244 and $\mathrm{Y}_{(+) i}$, the value of the Plus level of each variable $\mathrm{i}$.

245 The multiple regression analysis was performed using the XLSTAT software (Paris, France).

246 The 11 experimental factors tested in this study are listed in Table 2 that specifies the

247 concentrations or values characterizing the Minus and Plus levels in the experimental design.

248 The conditions used in each experiment are listed in Table S1. They were randomized and the

249 reference condition was performed in triplicate. The final cell concentration $\left(\mathrm{g}_{\mathrm{CDW}} \cdot \mathrm{L}^{-1}\right)$ was

250 selected as the response variable to describe the effect of the factors on the growth step. The

251 percentage of viable cells at the beginning of the bioconversion stage was included in the

252 analysis. Three response variables were chosen to characterize the effect of the experimental

253 factors on the bioconversion performance: total quantity of 3-HP produced at the end of the

254 fed-batch bioconversion $\left(\mathrm{g}_{3}-\mathrm{HP}\right), 3-\mathrm{HP}$ production yield $\left(\mathrm{g}_{3-\mathrm{HP}} \cdot \mathrm{g}_{\mathrm{CDW}}{ }^{-1}\right)$ and duration of the 255 bioconversion (h). 

effects of culture conditions of $L$. reuteri DSM 17938 on its bioconversion performances

\begin{tabular}{lll}
\hline Medium components & Minus level & Plus level \\
\hline Additional glucose $\left(\mathrm{g} \cdot \mathrm{L}^{-1}\right)$ & 20 & 50 \\
\hline Additional yeast extract $\left(\mathrm{g} \cdot \mathrm{L}^{-1}\right)$ & 0 & 25 \\
\hline Phytone peptone $\left(\mathrm{g} \cdot \mathrm{L}^{-1}\right)$ & 0 & 25 \\
\hline Tween $80\left(\mathrm{~g} \cdot \mathrm{L}^{-1}\right)$ & 1 & 5 \\
\hline Vitamin $\mathrm{B} 12\left(\mathrm{mg} \cdot \mathrm{L}^{-1}\right)$ & 0 & 0.1 \\
\hline 1,2-propanediol $\left(3 \mathrm{~g} \cdot \mathrm{L}^{-1}\right)$ & 0 & 3 \\
\hline Cysteine $\left(\mathrm{g} \cdot \mathrm{L}^{-1}\right)$ & 0 & 1 \\
\hline Betaine $\left(\mathrm{g} \cdot \mathrm{L}^{-1}\right)$ and & 0 & 0.234 \\
$\mathrm{KCl}\left(\mathrm{g} \cdot \mathrm{L}^{-1}\right)$ & 0 & 0.745 \\
\hline
\end{tabular}

\section{Culture conditions}

\begin{tabular}{lll}
\hline Temperature $\left({ }^{\circ} \mathrm{C}\right)$ & 33 & 37 \\
\hline $\mathrm{pH}$ & 5.5 & 6.0 \\
\hline Base type (and concentration, in $\left.\mathrm{mol} \cdot \mathrm{L}^{-1}\right)$ & $\mathrm{NH} 4 \mathrm{OH}(14.8)$ & $\mathrm{NaOH}(8.75)$ \\
\hline
\end{tabular}

\section{Results and Discussion}

Kinetics of cell growth and glycerol bioconversion in the reference condition of the experimental design

262 In order to assess the kinetics of L. reuteri DSM 17938 in the reference condition, three replicates were performed. The experimental conditions are summarized with the code T1 in

264 the Table S1. Figure 1 shows the cell growth kinetics during the first phase, whereas Figure 2

265 displays the bioconversion kinetics of during the second step. 


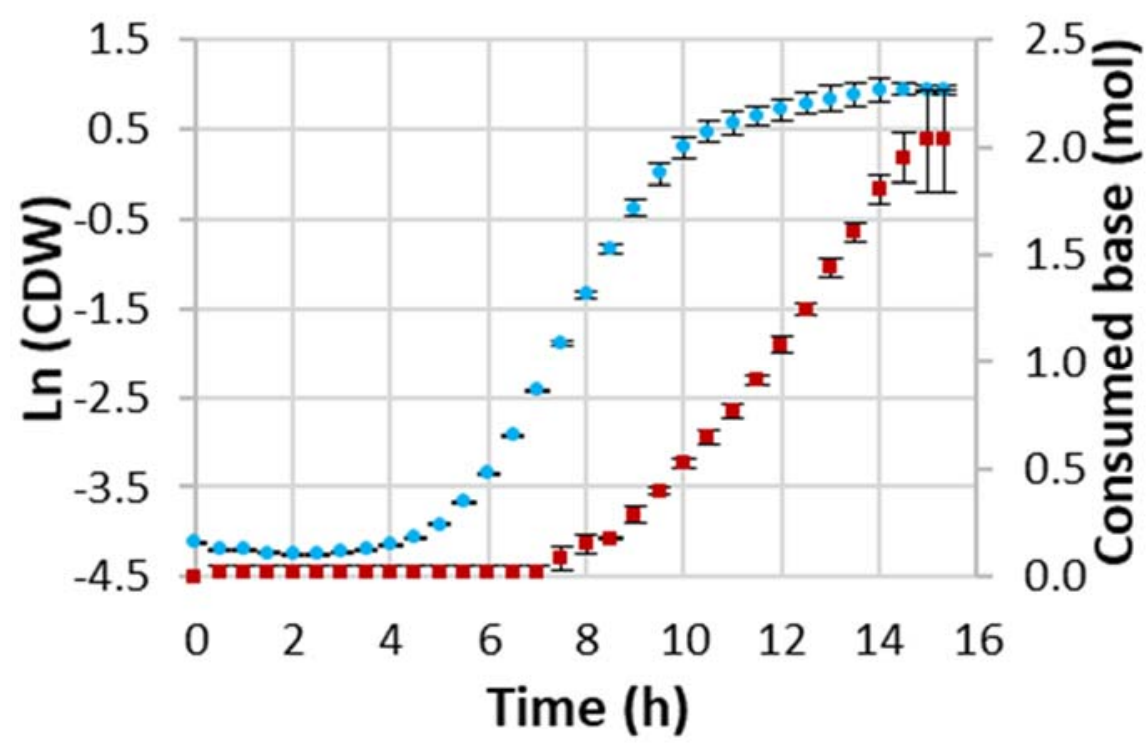

Figure 1. Kinetics of $L$. reuteri DSM 17938 growth and acidification in the reference condition

Blue circle: cell dry weight $(\mathrm{CDW})$ expressed in $\mathrm{g}_{\mathrm{CDW}} \cdot \mathrm{L}^{-1}$; red square: consumed base; error bars correspond to standard errors from 3 replicates.

From Figure 1, two successive exponential growth phases were observed, with different specific growth rates that were calculated at $0.99( \pm 0.002) h^{-1}$ from $6 \mathrm{~h}$ to $9.5 \mathrm{~h}$, and then 0.13 $( \pm 0.01) \mathrm{h}^{-1}$, between $10.5 \mathrm{~h}$ and $14 \mathrm{~h}$, indicating that a substrate limitation occurred. This limitation cannot be due to a lack of carbon source as the glucose concentration was equal to $8.5( \pm 1.7) \mathrm{g} \cdot \mathrm{L}^{-1}$ at $10 \mathrm{~h}$. It may be caused by a lack of another nutrient source that was not searched in this study or by an inhibition of bacterial growth by the accumulation of lactic acid (41) and ethanol (42) that reached $4.6( \pm 0.9)$ and $2.0( \pm 0.4) \mathrm{g} \cdot \mathrm{L}^{-1}$, respectively after $10 \mathrm{~h}$. Meanwhile, no limitation was observed on organic acid production since the base was consumed regularly during the logarithm phase. However, when no more glucose was available in the medium, the base consumption stopped suddenly, together with growth, indicating that no more organic acid was synthesized. These results were confirmed by HPLC analysis. The base profile was then used to precisely detect the growth stop. Quantitative results obtained within the three reference experiments are summarized with the codes T1a, T1b and T1c in Table S2. The carbon mass balance during growth was verified at $104.33( \pm 3.82) \%$ for all the 
experiments performed. This value was slightly higher than $100 \%$, which could be explained

287

288

289

290

291

292

293

294

295

296

297

298

299

300

301

302

303

304

305

306

307

308

309

310

by the fact that some carbon used for the growth may come from other sources than glucose (for instance yeast extract) that could not be quantified. A final CDW value of $3.3( \pm 0.3)$ $\mathrm{g}_{\mathrm{CDW}} \cdot \mathrm{L}^{-1}$ was achieved, which was similar to previous results obtained with the same L. reuteri strain at $\mathrm{pH} 5.5\left(3.1 \mathrm{gCDw} \cdot \mathrm{L}^{-1}\right)(12)$. From HPLC analyses, the presence of lactic acid $(16.4( \pm$ 1.2) $\left.g \cdot \mathrm{L}^{-1}\right)$, acetic acid $\left(3.7( \pm 0.4) \mathrm{g} \cdot \mathrm{L}^{-1}\right)$ and ethanol $\left(7.6( \pm 0.8) \mathrm{g} \cdot \mathrm{L}^{-1}\right)$ was detected. The molar ratio of the sum of (ethanol + acetic acid) to lactic acid was close to $1(0.97( \pm 0.05)$ $\left.\mathrm{mol} \cdot \mathrm{mol}^{-1}\right)$. This value indicated that the PK pathway was prevalent in this heterofermentative L. reuteri strain, as previously observed by Burgé et al. (18). This value indicated that the PK pathway was prevalent in this heterofermentative L. reuteri strain, as previously observed by Burgé et al. (2015) (18). This result, obtained at controlled $\mathrm{pH}$, is consistent with previous studies on L. reuteri ATCC 55730 (19) and L. reuteri DSM 17938 grown in free-pH conditions (18). Regarding the efficiency of ATP synthesis, the domination of PK pathway is unfavorable compared to EMP pathway (production of 1 instead of 2 ATP). Nevertheless, by producing less organic acid, the PK pathway reduced the inhibition of the bacteria by lactic acid, thus improving their survival in an acidic environment (18).

Kinetics of glycerol bioconversion into 3-HP and 1,3-PDO are illustrated in Figure 2. The carbon mass balance during bioconversion was verified at $100.12( \pm 4.39) \%$. This step was performed using resting cells of $L$. reuteri, to allow the $\mathrm{NAD}^{+}$regeneration through $3-\mathrm{HP}$ production in place of lactate production. The glycerol was fed into the bioreactor at a constant feeding rate $0.5 \mathrm{gglycerol} \mathrm{h}^{-1}$ until the bioconversion stopped. The slope of glycerol consumption was constant (Figure 2), which indicated that all substrate was consumed as and when it was supplied. The glycerol consumption ceased at the same time as the base consumption, which was confirmed from HPLC analyses. This indicated that the base profile was a relevant indicator of the cessation of the bioconversion. 


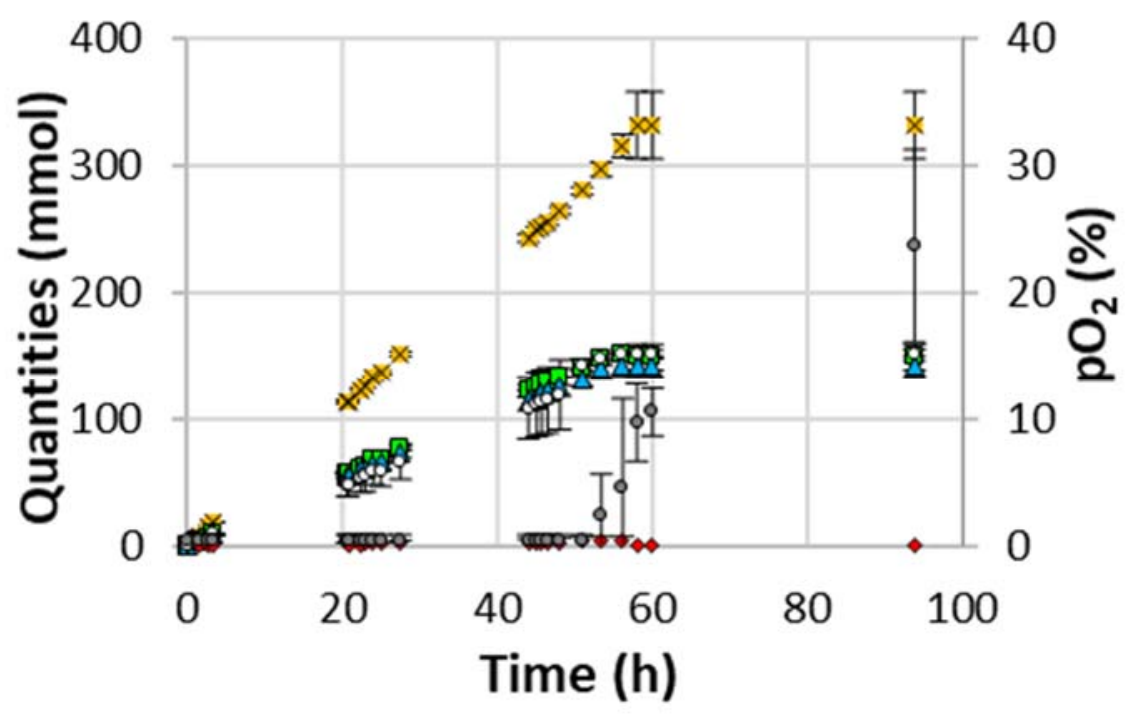

Figure 2. Kinetics of glycerol bioconversion into 3-HP and 1,3-PDO by L. reuteri DSM

Yellow square with cross: consumed glycerol; green square: 3-HP; blue triangle: 1,3-PDO; red diamond: 3-HPA; white circle: consumed $\mathrm{NH}_{4} \mathrm{OH}$; grey circle: dissolved $\mathrm{O}_{2}$; error bars correspond to standard errors from 3 replicates.

After $55.8( \pm 2.2)$ h of bioconversion, two final products 3-HP and 1,3-PDO were obtained at final concentrations of $11.8( \pm 0.5) \mathrm{g} \cdot \mathrm{L}^{-1}$ and $9.5( \pm 0.5) \mathrm{g} \cdot \mathrm{L}^{-1}$, respectively. In comparison to the previous study of Dishisha et al. (2015) (16) using L. reuteri DSM 20016, the duration of bioconversion was similar ( $56 \mathrm{~h}$ compared to $58 \mathrm{~h}$ ), but the final 3-HP titer was $16 \%$ lower which was explained by the lower substrate feeding rate used in our study $\left(0.5 \mathrm{gglycerol} \cdot \mathrm{h}^{-1}\right.$ compared to $0.75 \mathrm{gglycerol} \cdot \mathrm{h}^{-1}$ ). The maximal 3-HPA content detected into the bioconversion broth was equal to $0.4 \pm 0.1 \mathrm{~g} \cdot \mathrm{L}^{-1}$. This value was about 10 times lower than the minimum inhibition concentration reported for L. reuteri DSM $20016\left(2.2-3.7 \mathrm{~g} \cdot \mathrm{L}^{-1}\right)$ (43), thus protecting it from detrimental effects (44). 3 -HP was produced equimolarly to 1,3-PDO, as the molar ratio was equal to $1.04 \pm 0.06 \mathrm{~mol} \cdot \mathrm{mol}^{-1}$, which indicated that the redox balance between $\mathrm{NAD}^{+}$and NADH was well maintained during the glycerol bioconversion. These results were close to those obtained by (12) who obtained a molar ratio of $1 \mathrm{~mol} \cdot \mathrm{mol}^{-1}$. The molar ratio between 3-HP and $\mathrm{NH}_{4} \mathrm{OH}$ was equal to $1.08 \pm 0.01 \mathrm{~mol} \cdot \mathrm{mol}^{-1}$, which is a little bit higher than 
1. As no other organic acid was detected from HPLC analyses, this small divergence can be

332 explained by a slight volatilization of the ammonia solution during the bioconversion. The total amount of 3-HP and 1,3-PDO produced at the end of the fed-batches were respectively equal to $13.4 \pm 0.9 \mathrm{~g}$ and $10.8 \pm 0.7 \mathrm{~g}$. These values were lower than those obtained by (16) due to the lower supply rate of glycerol as aforementioned. The 3-HP production yield was equal to $0.78 \pm 0.11 \mathrm{~g}_{3}-\mathrm{HP} . \mathrm{gCDW}^{-1}$, which was also lower than the higher value reported by (16).

Micro-aerobic conditions were applied in this study to facilitate glycerol metabolism toward 3HP production (17). The partial pressure of dissolved oxygen $\left(\mathrm{pO}_{2}\right)$ in the medium remained at a value lower than $0.5 \%$ until $51 \mathrm{~h}$ (Figure 2). At that time, the base consumption started to decrease, 3-HP and 1,3-PDO production ceased and $\mathrm{pO}_{2}$ increased. This link between the $\mathrm{pO}_{2}$ increase and the cessation of bioconversion is consistent with previous works $(17,45)$. This $\mathrm{pO}_{2}$ increase may be due to a reduction of the activity of the enzyme $\mathrm{NAD}(\mathrm{P}) \mathrm{H}$ oxidase that uses molecular oxygen as a substrate (45). We may hypothesize that the stopping of the bioconversion corresponded to a global dysfunction of the whole enzyme pool of bacterial cells. In that case, the catalytic work of the $\mathrm{NAD}(\mathrm{P}) \mathrm{H}$ oxidase stopped concomitantly with that of the enzymes of the pdu operon that drives the 3-HP bioproduction. The decrease in oxygen consumption is thus observed simultaneously to the reduction in 3-HP bioproduction. Moreover, our results indicate that the $\mathrm{pO}_{2}$ measurement may constitute an early on-line indicator of the cessation of bioconversion, which is an original approach for controlling the fed-batch bioconversion of glycerol into 3-HP.

\section{Effect of culture conditions on Lactobacillus reuteri DSM 17938 growth performances} According to the Plackett and Burman experimental design (Table S1), various growth medium recipes and culture conditions were designed to screen, among 11 factors, the best combination to improve bacterial growth. The final biomass concentration $\left(\mathrm{gCDW}_{\mathrm{CD}} \cdot \mathrm{L}^{-1}\right)$ was retained as the variable to characterize the bacterial growth performance. Indeed, as the growth occurred during night without being monitored by a biomass probe, the effect of the conditions on the 
Table 3. Effect of growth conditions on cell concentration and on glycerol bioconversion performances of $L$. reuteri DSM 17938

\begin{tabular}{|c|c|c|c|c|}
\hline & $\begin{array}{l}\text { Cell concentration } \\
\text { at the end of growth }\left(\mathrm{g}_{\mathrm{CDW}} \cdot \mathrm{L}^{-1}\right)\end{array}$ & $\begin{array}{l}\text { Total quantity of 3- } \\
\text { HP produced (g) }\end{array}$ & $\begin{array}{l}\text { Bioconversion } \\
\text { duration (h) }\end{array}$ & $\begin{array}{l}\text { 3-HP production yield } \\
\left(\mathrm{g}_{3-\mathrm{HP}} \cdot \mathrm{g}_{\mathrm{CDW}}{ }^{-1}\right)\end{array}$ \\
\hline Constant & 3.90 & 14.12 & 64.1 & 0.75 \\
\hline Additional glucose & $0.58 * *$ & ns & $4.0 * *$ & $-0.23 * *$ \\
\hline Additional yeast extract & ns & ns & ns & ns \\
\hline Phytone peptone & ns & $0.94 *$ & $5.7 * *$ & $0.11 *$ \\
\hline Tween 80 & ns & $0.84 *$ & $2.1 *$ & $0.10 *$ \\
\hline Vitamin B12 & ns & $-2.16^{* *}$ & $-10.6 * * *$ & $-0.15^{* *}$ \\
\hline 1,2-propanediol & ns & $1.03 *$ & $4.5^{* *}$ & $0.093 *$ \\
\hline Cysteine & ns & ns & ns & $-0.10 *$ \\
\hline Betaine and $\mathrm{KCl}$ & ns & ns & $4.6^{* *}$ & $0.10^{*}$ \\
\hline Temperature & $0.53 * *$ & ns & $2.1^{*}$ & $-0.15^{* *}$ \\
\hline$\overline{\text { pH }}$ & ns & ns & ns & $0.096^{*}$ \\
\hline Base & ns & ns & ns & ns \\
\hline$\overline{\mathbf{R}^{2}}$ & 0.873 & 0.893 & 0.978 & 0.919 \\
\hline
\end{tabular}

Confidence level: * $90 \% ; * * 95 \%$;** $99 \%$; ns: not significant; $\mathrm{R}^{2}$ adjusted for degree of freedom. 
specific growth rate could not be established. The results obtained from the 14 experiments are summarized in Table S2 and were used for statistical analyses. From Table 3, only two factors displayed a significant effect on $L$. reuteri DSM 17938 final concentration: the addition of glucose and the higher temperature, which positively influenced the final biomass concentration, by $15 \%$ and $20 \%$, respectively. This result was confirmed by considering the number of viable cells at the end of the culture, enumerated by flow cytometry. It was improved by $34 \%$ in the presence of $50 \mathrm{~g} \cdot \mathrm{L}^{-1}$ glucose, which matches with the aforementioned result. This positive effect of glucose on L. reuteri growth is consistent with early studies $(18,19,21)$. Conversely, the addition of yeast extract or phytone peptone to the MRS medium as nitrogen sources did not improved neither the biomass concentration nor the cell viability. This result is contrary to those obtained in previous studies $(21,24)$ and suggested that the growth limitation previously observed in the growth phase cannot be justified by a lack of these nutrients. The existence of interactions between factors, which cannot be considered by the type of experimental design used in our study, can partly explain this observation.

Tween 80 and cysteine are both growth factors for lactobacilli. However, the current supplementation of these compounds at $5 \mathrm{~g} \cdot \mathrm{L}^{-1}$ and $1 \mathrm{~g} \cdot \mathrm{L}^{-1}$ respectively, seemed not enough to increase the cell concentration. The addition of vitamin B12, 1,2-PDO and betaine together with $\mathrm{KCl}$ did not affect the growth, which was expected as they were added to act during the bioconversion stage.

The temperature positively affected the biomass concentration that was higher at $37{ }^{\circ} \mathrm{C}$ than at $33{ }^{\circ} \mathrm{C}$, which was confirmed by flow cytometry measurements $\left(5.6 .10^{9} \mathrm{cell} \cdot \mathrm{mL}^{-1}\right.$ instead of 4.5.10 $0^{9}$ cell $\left.\cdot \mathrm{mL}^{-1}\right)$. This result is consistent with the conditions found in the digestive tract, the ecological niche of L. reuteri (46).

Finally, the $\mathrm{pH}$ value $\left(\mathrm{pH} 5.5\right.$ or $\mathrm{pH}$ 6.0) and the base used for $\mathrm{pH}$ control $\left(\mathrm{NH}_{4} \mathrm{OH}\right.$ or $\left.\mathrm{NaOH}\right)$ did not significantly modify the final cell concentration of L. reuteri DSM 17938 . Therefore, they can be used equally to maintain the $\mathrm{pH}$ during the growth phase. 
The Plackett and Burman experimental design allowed identifying the growth medium composition and culture conditions that affected the ability of L. reuteri DSM 17938 to further perform glycerol bioconversion into 3-HP. During all experiments, no residual glycerol was detected in the bioconversion broth. Table 3 summarizes the results obtained from the 14 different experiments (including three replicates of the reference condition), to explain the effects of the 11 factors on three variables that characterized the bioconversion step: quantity of 3-HP produced, bioconversion duration and 3-HP production yield. From Table 3, nine factors displayed a statistically significant effect on these variables. Only two factors did not show any significant effect on the characteristic variables of the 3-HP production step: the addition of yeast extract and the type of base used for $\mathrm{pH}$ control. The three variables were positively influenced by the addition of phytone peptone, Tween 80 and 1,2-PDO but negatively by a vitamin B12 supplementation. A high glucose concentration and a high temperature positively affected the bioconversion duration but negatively the 3 -HP production yield. The addition of betaine enhanced the bioconversion duration and the 3-HP production yield. Finally, the addition of cysteine and a low $\mathrm{pH}$ value negatively influenced the 3-HP production yield. In addition to these three variables, the quantity of 1,3-PDO produced and the molar ratio between 3-HP and 1,3-PDO were also determined and will be analyzed when required.

As explained above, the growth medium supplementation with a higher glucose concentration led to a higher quantity of harvested biomass and a higher percentage of viable cells at the beginning of bioconversion. However, in the experimental conditions chosen during the bioconversion step, no increase of 3-HP production was observed, which is explained by the moderate glycerol feeding rate $\left(0.5 \mathrm{gglycerol} \cdot \mathrm{h}^{-1}\right)$ used in this study. In other words, the quantity 
As a consequence, the specific feeding rate of glycerol was lower in the condition of the higher level of glucose addition $\left(18.1 \pm 3.5 \mathrm{mgglycerol} \cdot \mathrm{gCDW}^{-1} \cdot \mathrm{h}^{-1}\right)$ as compared to that observed with the lower level of glucose addition $\left(32.9 \pm 8.6 \mathrm{mg}_{\text {glycerol }} \cdot \mathrm{g}_{\mathrm{CDW}}{ }^{-1} \cdot \mathrm{h}^{-1}\right)$. This observation was supported by the decrease of the 3-HP production yield (- $30.7 \%)$. The longer duration of bioconversion $(+6.2 \%)$ noticed when the cells were previously cultivated in the presence of a higher glucose concentration might be explained by a better enzymatic activity of the total bacterial population at the beginning of bioconversion stage, as observed by $\mathrm{cF}$ fluorescence measurements. This better activity allowed the cells to convert glycerol for a longer time.

Results showed that phytone peptone slightly promoted the 3-HP bioproduction whereas yeast extract did not (Table 3). As these two compounds act as amino acid sources, the positive effect of phytone peptone can be related to a specific amino acid composition that differs from that of yeast extract. From the information available from the suppliers, phytone peptone contained more arginine, histidine, tyrosine (+ $200 \%)$ and glycine $(+90 \%)$ than yeast extract. Particularly, the amino acids arginine and glycine have been shown to be used for energy production and were linked to the survival of Lactococcus lactis under starvation (47) and Lactobacillus sakei under acidic conditions (48).

A positive effect of Tween 80 supplementation was observed on cell ability to produce 3-HP (Table 3) that is consistent with (21). This component is known to support cell division of lactobacilli by modifying the cell membrane fatty acids composition (49). In addition, it induces a down-regulation of the de novo fatty acid synthesis that helps the cells to save intracellular energy (28).

Addition of 1,2-PDO significantly improved the three variables characterizing the bioconversion step (Table 3), in agreement with (16). Here we consider that due to the structural similarity between glycerol and 1,2-PDO, the addition of the latter in the growth medium might help the cells to prepare their enzymatic machinery. 
434

435

436

437

438

439

440

441

442

443

444

445

446

447

448

449

450

451

452

453

454

455

456

457

458

459

A negative effect of the addition of $0.1 \mathrm{mg} \cdot \mathrm{L}^{-1}$ vitamin $\mathrm{B} 12$ in the growth medium was observed on the quantity of 3-HP produced, the bioconversion duration and the 3-HP production yield (Table 3). This result was an unintended outcome because this compound is a required cofactor of the first enzyme of the pdu metabolic pathway (12). It was reported that a supplementation of vitamin $\mathrm{B} 12$ at $0.1 \mathrm{mg} \cdot \mathrm{L}^{-1}$ in the bioconversion medium showed a positive impact on 3-HP production by L. reuteri DSM 17938 (21). Thus, it could be hypothesized that the early addition of exogenous vitamin B12 in the growth medium may reduce the ability of the cells to produced endogenous vitamin B12 during the further step of bioconversion.

The addition of betaine together with $\mathrm{KCl}$ led to a longer bioconversion, together with a higher production yield (Table 3) that can be explained by the protective effect of betaine to osmotic stress (50). This result can be linked to that of (31) who related a higher intracellular betaine content to a more rigid membrane that led to the reduction of water exchange between the intracellular and extracellular compartments in L. buchneri R1102 (31).

The addition of cysteine was related to a reduction of the 3-HP production yield (Table 3 ). This observation can be explained by its negative effect on vitamin B12 biosynthesis by L. reuteri, as previously demonstrated (10). As another hypothesis, cysteine may counteract the oxygen utilization by the cells, as suggested by (27).

Regarding the influence of the growth temperature on the further bioconversion step, a higher 3-HP production yield but shorter bioconversion duration was observed when the growth was conducted at $33{ }^{\circ} \mathrm{C}$ instead of $37{ }^{\circ} \mathrm{C}$ (Table 3). As the glycerol feeding rate was fixed at a moderate value of $0.5 \mathrm{gglycerl} \cdot \mathrm{h}^{-1}$ during bioconversion, this higher 3-HP production yield was the consequence of the lower cell concentration achieved at the end of the growth phase.

The $\mathrm{pH}$ value during growth had a very little effect on the bioconversion step. Only the 3-HP production yield decreased slightly when the $\mathrm{pH}$ was reduced from 6.0 to 5.5 (Table 3 ). This difference could be ascribed to a small, even not significant, increase in the final biomass concentration when the growth was conducted at $\mathrm{pH}$ 5.5. Finally, it was demonstrated that the 
type of base used had no effect, thus allowing us to use them indiscriminately. However, as the

461

462

463

464

465

466

467

468

469

470

471

472

473

474

475

476

477

478

479

480

481

482

483

484

485

base $\mathrm{NH}_{4} \mathrm{OH}$ prevents the formation of salt in the medium, this base might be preferred to facilitate further downstream processes.

Selected growth conditions that improve L. reuteri DSM 17938 ability to convert glycerol into 3-HP

In order to enhance the capacity of L. reuteri DSM 17938 to perform 3-HP bioproduction at a glycerol feeding rate of $0.5 \mathrm{gglycerol} \cdot \mathrm{h}^{-1}$, the growth conditions leading to the best 3-HP titer, bioconversion duration and 3-HP production yield have been identified. They consist in MRS medium added with glucose $\left(20 \mathrm{~g} \cdot \mathrm{L}^{-1}\right)$, phytone peptone $\left(25 \mathrm{~g} \cdot \mathrm{L}^{-1}\right)$, Tween $80\left(4 \mathrm{~g} \cdot \mathrm{L}^{-1}\right), 1,2-$ PDO $\left(3 \mathrm{~g} \cdot \mathrm{L}^{-1}\right)$, betaine $\left(0.234 \mathrm{~g} \cdot \mathrm{L}^{-1}\right)$ plus $\mathrm{KCl}\left(0.745 \mathrm{~g} \cdot \mathrm{L}^{-1}\right)$, temperature $\left(33^{\circ} \mathrm{C}\right)$ and $\mathrm{pH} 6.0$.

No additional yeast extract, no supplementation with vitamin B12 nor cysteine were required, and the base to control the $\mathrm{pH}$ was likely unimportant. This set of conditions has been assayed to demonstrate its positive effects on the bioconversion performances. In comparison to the reference condition, the 3 -HP titer was increased from $11.8 \pm 0.5 \mathrm{~g} \cdot \mathrm{L}^{-1}$ to $14.7 \mathrm{~g} \cdot \mathrm{L}^{-1}$, the bioconversion duration from $55.8 \pm 2.2 \mathrm{~h}$ to $88.6 \mathrm{~h}$, and the 3 -HP production yield from $0.8 \pm$ $0.1 \mathrm{~g}_{3-\mathrm{HP}} \cdot \mathrm{g}_{\mathrm{CDW}}{ }^{-1}$ to $2.0 \mathrm{~g}_{3-\mathrm{HP}} \mathrm{g}_{\mathrm{CDW}}{ }^{-1}$. In addition, the specific 3 -HP production rate was improved from $14.0 \pm 2.5 \mathrm{mg}_{3-\mathrm{HP}} \cdot \mathrm{gCDW}^{-1} \cdot \mathrm{h}^{-1}$ to $22.5 \mathrm{mg}_{3-\mathrm{HP}} \cdot \mathrm{g}_{\mathrm{CDW}}{ }^{-1} \cdot \mathrm{h}^{-1}$. As the cell concentration at the end of the growth phase $\left(3.0 \mathrm{gCDw} \cdot \mathrm{L}^{-1}\right)$ was similar to that of the reference condition $(3.3$ $\left.\pm 0.3 \mathrm{gCDW} \cdot \mathrm{L}^{-1}\right)$, this improvement could be explained by a better ability of each cell to produce 3-HP from glycerol. This was supported by the higher ratio between 3-HP production to enzymatically-active cells determined by flow cytometry, which increased from $0.98 \pm 0.21 \mathrm{~g}_{3}$ -

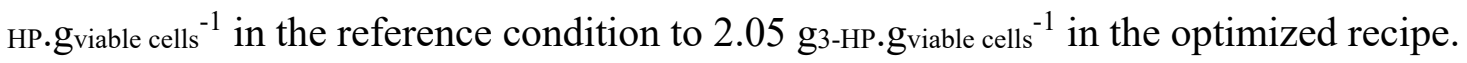

In conclusion, the influence of various growth conditions was assessed on the growth efficiency and on the ability of resting cells of L. reuteri DSM 17938 to produce 3-HP at a given glycerol feeding rate of $0.5 \mathrm{~g} \cdot \mathrm{h}^{-1}$. The implementation of a Plackett and Burman experimental design 
enabled 11 factors to be tested. The supplementation of MRS medium with glucose and the use of a higher temperature (i.e. $37^{\circ} \mathrm{C}$ ) induced a greater cell quantity at the end of the growth phase. Meanwhile, the addition of phytone peptone, Tween 80, 1,2-PDO, betaine with $\mathrm{KCl}$ and the use of a suboptimal temperature together with an optimal $\mathrm{pH}$, were recognized as options to improve the bioconversion duration and the 3-HP production yield. The best set of conditions has been validated as it enhanced the 3 -HP titer $(+25 \%)$, the 3 -HP production yield $(+150 \%)$ and the 3-HP specific production rate $(+61 \%)$.

With the aim of further improving the 3-HP bioproduction by L. reuteri DSM 17938, the environmental conditions during the bioconversion step will have to be optimized, together with avoiding 3-HPA accumulation. Finally, in order to better understand the cellular modifications that are linked to the improvement of 3-HP bioproduction, a more in-depth analysis of the physiological state of the cells may be done, mainly by using omic methods.

\section{Acknowledgments}

The authors thank URD ABI-AgroParisTech (Pomacle, France) that performed 3-HPA synthesis for HPLC standard. We also offer our thanks to Sarrah Ghorbal and Marielle Bouix for flow cytometry training and analysis. Mrs. Nguyen acknowledges the Vietnamese government for providing her scholarship.

\section{References}

1. Lüthi-Peng, Q., Schärer, S., and Puhan, Z.: Production and stability of 3hydroxypropionaldehyde in Lactobacillus reuteri, Applied Microbiology and Biotechnology 60, 73-80 (2002).

2. Gokarn, R. R., Selifonova, O. V., Jessen, H. J., Gort, S. J., Selmer, T., and Buckel, W.: 3-Hydroxypropionic acid and other organic compounds US7186541B2 186-541 (2007). 
3. Tingirikari, J. M. R., Ahmed, S., and Yata, V. K.: Chapter 6, 3-hydroxy-propionic acid, pp. 101-117, in: Kaur Brar, S., Jyoti Sarma, S., and Pakshirajan, K. (Ed.), Platform Chemical Biorefinery. Elsevier, Amsterdam (2016).

4. Bozell, J. J. and Petersen, G. R.: Technology development for the production of biobased products from biorefinery carbohydrates - the US Department of Energy's "Top 10" revisited, Green Chemistry, 12, 539-554 (2010).

5. Chavez-Gonzalez, M. L., Balagurusamy, N., and Aguilar, C. N.: Advances in Food Bioproducts and Bioprocessing Technologies, pp. 594. CRC Press (2019).

6. Matsakas, L., Hrůzová, K., Rova, U., and Christakopoulos, P.: Biological production of 3-hydroxypropionic acid: An update on the current status, Fermentation, 4, 13-34 (2018).

7. de Fouchécour, F., Sánchez-Castañeda, A.-K., Saulou-Bérion, C., and Spinnler, H. E.: Process engineering for microbial production of 3-hydroxypropionic acid, Biotechnology Advances, 36, 1207-1222 (2018).

8. Chen, L., Gu, Q., Li, P., Chen, S., and Li, Y.: Genomic analysis of Lactobacillus reuteri WHH1689 reveals its probiotic properties and stress resistance, Food Science \& Nutrition, 7, 844-857 (2019).

9. Jiang, X., Meng, X., and Xian, M.: Biosynthetic pathways for 3-hydroxypropionic acid production, Applied Microbiology and Biotechnology, 82, 995-1003 (2009).

10. Santos, F., Teusink, B., Molenaar, D., van Heck, M., Wels, M., Sieuwerts, S., de Vos, W. M., and Hugenholtz, J.: Effect of amino acid availability on vitamin B12 production in Lactobacillus reuteri, Applied and Environmental Microbiology, 75, 3930-3936 (2009).

11. Lindlbauer, K. A., Marx, H., and Sauer, M.: 3-hydroxypropionaldehyde production from crude glycerol by Lactobacillus diolivorans with enhanced glycerol uptake, Biotechnology for Biofuels, 10, 295-295 (2017). 
12. Dishisha, T., Pereyra, L. P., Pyo, S.-H., Britton, R. A., and Hatti-Kaul, R.: Flux analysis of the Lactobacillus reuteri propanediol utilization pathway for production of 3hydroxypropionaldehyde, 3-hydroxypropionic acid and 1,3-propanediol from glycerol, Microbial Cell Factories, 13, 76-87 (2014).

13. Talarico, T. L., Axelsson, L. T., Novotny, J., Fiuzat, M., and Dobrogosz, W. J.: Utilization of glycerol as a hydrogen acceptor by Lactobacillus reuteri: Purification of 1,3propanediol: $\mathrm{NAD}^{+}$oxidoreductase, Applied and Environmental Microbiology, 56, 943 948 (1990).

14. Sabet-Azad, R., Linares-Pastén, J. A., Torkelson, L., Sardari, R. R., and Hatti-Kaul, R.: Coenzyme A acylating propionaldehyde dehydrogenase (PduP) from Lactobacillus reuteri: Kinetic characterization and molecular modeling, Enzyme and Microbial Technology, 53, 235-242 (2013).

15. Chen, L. and Hatti-Kaul, R.: Exploring Lactobacillus reuteri DSM20016 as a biocatalyst for transformation of longer chain 1,2-diols: Limits with microcompartment, PLoS One, 12, e0185734 (2017).

16. Dishisha, T., Pyo, S.-H., and Hatti-Kaul, R.: Bio-based 3-hydroxypropionic-and acrylic acid production from biodiesel glycerol via integrated microbial and chemical catalysis, Microbial Cell Factories, 14, 200-211 (2015).

17. Zabed, H. M., Zhang, Y., Guo, Q., Yun, J., Yang, M., Zhang, G., and Qi, X.: Cobiosynthesis of 3-hydroxypropionic acid and 1,3-propanediol by a newly isolated Lactobacillus reuteri strain during whole cell biotransformation of glycerol, Journal of Cleaner Production, 226, 432-442 (2019).

18. Burgé, G., Saulou-Bérion, C., Moussa, M., Allais, F., Athes, V., and Spinnler, H.: Relationships between the use of Embden Meyerhof pathway (EMP) or Phosphoketolase pathway (PKP) and lactate production capabilities of diverse Lactobacillus reuteri strains, Journal of Microbiology, 53, 702-710 (2015). 
19. Arsköld, E., Lohmeier-Vogel, E., Cao, R., Roos, S., Rådström, P., and van Niel, E. W. J.: Phosphoketolase pathway dominates in Lactobacillus reuteri ATCC 55730 containing dual pathways for glycolysis, Journal of Bacteriology, 190, 206-212 (2008).

20. Alazzeh, A. Y., Ibrahim, S. A., Song, D., Shahbazi, A., and AbuGhazaleh, A. A.: Carbohydrate and protein sources influence the induction of $\alpha$ - and $\beta$-galactosidases in Lactobacillus reuteri, Food Chemistry, 117, 654-659 (2009).

21. Couvreur, J., Teixeira, A., Allais, F., Spinnler, H.-E., Saulou-Bérion, C., and Clément, T.: Wheat and sugar beet coproducts for the bioproduction of 3hydroxypropionic acid by Lactobacillus reuteri DSM17938, Fermentation, 3, 32-44 (2017).

22. Ju, J.-H., Wang, D., Heo, S.-Y., Kim, M.-S., Seo, J.-W., Kim, Y.-M., Kim, D.-H., Kang, S.-A., Kim, C.-H., and Oh, B.-R.: Enhancement of 1,3-propanediol production from industrial by-product by Lactobacillus reuteri CH53, Microbial Cell Factories, 19, 6-16 (2020).

23. Ichinose, R., Fukuda, Y., Yamasaki-Yashiki, S., and Katakura, Y.: Suppression of lactate production of Lactobacillus reuteri JCM1112 by co-feeding glycerol with glucose, Journal of Bioscience and Bioengineering, 129, 110-115 (2020).

24. Atilola, O. A., Gyawali, R., Aljaloud, S. O., and Ibrahim, S. A.: Use of phytone peptone to optimize growth and cell density of Lactobacillus reuteri, Foods, 4, 318-327 (2015).

25. Ayad, A. A., Gad El-Rab, D. A., Ibrahim, S. A., and Williams, L. L.: Nitrogen sources effect on Lactobacillus reuteri growth and performance cultivated in date palm (Phoenix dactylifera L.) by-products, Fermentation, 6, 64-74 (2020).

26. Lozo, J., Begovic, J., Jovcic, B., Golić, N., and Topisirovic, L.: Effect of methionine and cysteine deprivation on growth of different natural isolates of Lactobacillus spp. in chemically defined media, Archives of Biological Sciences, 60, 509-517 (2008). 
27. Turner, M. S., Woodberry, T., Hafner, L. M., and Giffard, P. M.: The bspA locus of Lactobacillus fermentum BR11 encodes an L-cystine uptake system, Journal of Bacteriology, 181, 2192-2198 (1999).

28. Reitermayer, D., Kafka, T. A., Lenz, C. A., and Vogel, R. F.: Interrelation between Tween and the membrane properties and high pressure tolerance of Lactobacillus plantarum, BMC Microbiology, 18, 72-84 (2018).

29. Burgé, G., Saulou-Bérion, C., Moussa, M., Pollet, B., Flourat, A., Allais, F., Athès, V., and Spinnler, H.-E.: Diversity of Lactobacillus reuteri strains in converting glycerol into 3-hydroxypropionic acid, Applied Biochemistry and Biotechnology, 177, 923-939 (2015).

30. Sriramulu, D. D., Liang, M., Hernandez-Romero, D., Raux-Deery, E., Lünsdorf, H., Parsons, J. B., Warren, M. J., and Prentice, M. B.: Lactobacillus reuteri DSM 20016 produces cobalamin-dependent diol dehydratase in metabolosomes and metabolizes 1,2propanediol by disproportionation, Journal of Bacteriology, 190, 4559-4567 (2008).

31. Louesdon, S., Charlot-Rougé, S., Juillard, V., Tourdot-Maréchal, R., and Béal, C.: Osmotic stress affects the stability of freeze-dried Lactobacillus buchneri R1102 as a result of intracellular betaine accumulation and membrane characteristics, Journal of Applied Microbiology, 117, 196-207 (2014).

32. Polak-Berecka, M., Waśko, A., Kordowska-Wiater, M., Podleśny, M., Zdzislaw, T., and Kubik-Komar, A.: Optimization of medium composition for enhancing growth of Lactobacillus rhamnosus PEN using response surface methodology, Polish Journal of Microbiology, 59, 113-118 (2010).

33. Garro, M. S., de Valdez, G. F., and de Giori, G. S.: Temperature effect on the biological activity of Bifidobacterium longum CRL 849 and Lactobacillus fermentum CRL 251 in pure and mixed cultures grown in soymilk, Food Microbiology, 21, 511-518 (2004). 
34. Kandler, O., Stetter, K.-O., and Köhl, R.: Lactobacillus reuteri sp. nov., a new species of heterofermentative lactobacilli, Zentralblatt für Bakteriologie: I. Abt. Originale C: Allgemeine, Angewandte und ökologische Mikrobiologie, 1, 264-269 (1980).

35. El-Ziney, M. G.: Molecular and Probiotic Characterizations of Lactobacillus reuteri DSM 12246 and Impact of pH on Biomass and Metabolic Profile in Batch-Culture, Advances in Microbiology, 8, 13-30 (2018).

36. Hernández, A., Larsson, C. U., Sawicki, R., van Niel, E. W. J., Roos, S., and Håkansson, S.: Impact of the fermentation parameters $\mathrm{pH}$ and temperature on stress resilience of Lactobacillus reuteri DSM 17938, AMB Express, 9, 66-72 (2019).

37. Kristjansdottir, T., Bosma, E. F., Branco dos Santos, F., Özdemir, E., Herrgård, M. J., França, L., Ferreira, B., Nielsen, A. T., and Gudmundsson, S.: A metabolic reconstruction of Lactobacillus reuteri JCM 1112 and analysis of its potential as a cell factory, Microbial Cell Factories, 18, 186-205 (2019).

38. Ricci, M. A., Russo, A., Pisano, I., Palmieri, L., de Angelis, M., and Agrimi, G.: Improved 1,3-propanediol synthesis from glycerol by the robust Lactobacillus reuteri strain DSM 20016, Journal of Microbiology and Biotechnology, 25, 893-902 (2015).

39. Rault, A., Béal, C., Ghorbal, S., Ogier, J.-C., and Bouix, M.: Multiparametric flow cytometry allows rapid assessment and comparison of lactic acid bacteria viability after freezing and during frozen storage, Cryobiology, 55, 35-43 (2007).

40. Plackett, R. L. and Burman, J. P.: The design of optimum multifactorial experiments, Biometrika, 33, 305-325 (1946).

41. Papadimitriou, K., Alegría, Á., Bron, P. A., de Angelis, M., Gobbetti, M., Kleerebezem, M., Lemos, J. A., Linares, D. M., Ross, P., Stanton, C., and other seven authors: Stress physiology of lactic acid bacteria, Microbiology and molecular biology reviews: MMBR, 80, 837-890 (2016). 
42. van Bokhorst-van de Veen, H., Abee, T., Tempelaars, M., Bron, P. A., Kleerebezem, M., and Marco, M. L.: Short-and long-term adaptation to ethanol stress and its crossprotective consequences in Lactobacillus plantarum, Applied Environmental Microbiology, 77, 5247-5256 (2011).

43. Cleusix, V., Lacroix, C., Vollenweider, S., Duboux, M., and Le Blay, G.: Inhibitory activity spectrum of reuterin produced by Lactobacillus reuteri against intestinal bacteria, BMC Microbiology, 7, 101-110 (2007).

44. Schaefer, L., Auchtung, T. A., Hermans, K. E., Whitehead, D., Borhan, B., and Britton, R. A.: The antimicrobial compound reuterin (3-hydroxypropionaldehyde) induces oxidative stress via interaction with thiol groups, Microbiology, 156, 1589-1599 (2010).

45. Dishisha, T., Sabet-Azad, R., Arieta, V., and Hatti-Kaul, R.: Lactobacillus reuteri NAD(P)H oxidase: Properties and coexpression with propanediol-utilization enzymes for enhancing 3-hydroxypropionic acid production from 3-hydroxypropionaldehyde, Journal of Biotechnology, 289, 135-143 (2019).

46. Duar, R. M., Lin, X. B., Zheng, J., Martino, M. E., Grenier, T., Pérez-Muñoz, M. E., Leulier, F., Gänzle, M., and Walter, J.: Lifestyles in transition: Evolution and natural history of the genus Lactobacillus, FEMS Microbiology Reviews, 41, S27-S48 (2017).

47. Stuart, M. R., Chou, L. S., and Weimer, B. C.: Influence of carbohydrate starvation and arginine on culturability and amino acid utilization of Lactococcus lactis subsp. lactis, Applied and Environmental Microbiology, 65, 665-673 (1999).

48. Champomier Vergès, M.-C., Zuñiga, M., Morel-Deville, F., Pérez-Martínez, G., Zagorec, M., and Ehrlich, S. D.: Relationships between arginine degradation, $\mathrm{pH}$ and survival in Lactobacillus sakei, FEMS Microbiology Letters, 180, 297-304 (1999). 
659

660

661

662

663

664

665

49. Béal, C., Fonseca, F., and Corrieu, G.: Resistance to freezing and frozen storage of Streptococcus thermophilus is related to membrane fatty acid composition, Journal of Dairy Science, 84, 2347-2356 (2001).

50. Kets, E. P. W. and de Bont, J. A. M.: Protective effect of betaine on survival of Lactobacillus plantarum subjected to drying, FEMS Microbiology Letters, 116, 251-256 (1994). 
Table S1. Experimental factors and their levels in the Plackett and Burman experimental design

\begin{tabular}{|c|c|c|c|c|c|c|c|c|c|c|c|}
\hline \multirow{2}{*}{$\begin{array}{l}\text { Experiment } \\
\text { code }\end{array}$} & \multicolumn{11}{|c|}{ Experimental factors } \\
\hline & $\begin{array}{c}\text { Additional } \\
\text { glucose } \\
\left(\mathrm{g} \cdot \mathbf{L}^{-1}\right)\end{array}$ & $\begin{array}{c}\text { Additional } \\
\text { yeast } \\
\text { extract } \\
\left(\mathrm{g} \cdot \mathbf{L}^{-1}\right)\end{array}$ & $\begin{array}{l}\text { Phytone } \\
\text { peptone p } \\
\left(\mathrm{g} \cdot \mathbf{L}^{-1}\right)\end{array}$ & $\begin{array}{l}1,2- \\
\text { ropanediol } \\
\left(\mathrm{g} \cdot \mathrm{L}^{-1}\right)\end{array}$ & $\begin{array}{l}\text { Cysteine } \\
\left(\mathrm{g} \cdot \mathrm{L}^{-1}\right)\end{array}$ & $\begin{array}{c}\text { Betaine } \\
\left(\mathrm{g} \cdot \mathbf{L}^{-1}\right) \\
\text { and } \mathbf{K C l} \\
\left(\mathrm{g} \cdot \mathbf{L}^{-1}\right)\end{array}$ & $\begin{array}{c}\text { Tween } \\
80 \\
\left(\mathrm{~g} \cdot \mathrm{L}^{-1}\right)\end{array}$ & $\begin{array}{c}\text { Vitamin } \\
\text { B12 } \\
\left(\mathrm{mg} \cdot \mathrm{L}^{-1}\right)\end{array}$ & $\begin{array}{c}\text { Temperature } \\
\left({ }^{\circ} \mathrm{C}\right)\end{array}$ & pH & $\begin{array}{c}\text { Base type } \\
\text { (and } \\
\text { concentration, } \\
\text { in } \mathbf{m o l} \cdot \mathrm{L}^{-1} \text { ) }\end{array}$ \\
\hline T1 & 20 & 0 & 0 & 0 & 0 & 0 and 0 & 1 & 0 & 37 & 6.0 & $\mathrm{NH}_{4} \mathrm{OH}(14.8)$ \\
\hline $\mathbf{T} 2$ & 50 & 0 & 25 & 0 & 0 & 0 and 0 & 5 & 0.1 & 33 & 6.0 & $\mathrm{NaOH}(8.75)$ \\
\hline T3 & 50 & 25 & 0 & 3 & 0 & 0 and 0 & 1 & 0.1 & 37 & 5.5 & $\mathrm{NH}_{4} \mathrm{OH}(14.8)$ \\
\hline T4 & 20 & 25 & 25 & 0 & 1 & 0 and 0 & 1 & 0 & 37 & 5.5 & $\mathrm{NaOH}(8.75)$ \\
\hline T5 & 50 & 0 & 25 & 3 & 0 & $\begin{array}{c}0.234 \text { and } \\
0.745\end{array}$ & 1 & 0 & 33 & 5.5 & $\mathrm{NaOH}(8.75)$ \\
\hline T6 & 50 & 25 & 0 & 3 & 1 & 0 and 0 & 5 & 0 & 33 & 6.0 & $\mathrm{NaOH}(8.75)$ \\
\hline T7 & 50 & 25 & 25 & 0 & 1 & $\begin{array}{c}0.234 \text { and } \\
0.745\end{array}$ & 1 & 0.1 & 33 & 6.0 & $\mathrm{NH}_{4} \mathrm{OH}(14.8)$ \\
\hline T8 & 20 & 25 & 25 & 3 & 0 & $\begin{array}{c}0.234 \text { and } \\
0.745\end{array}$ & 5 & 0 & 37 & 6.0 & $\mathrm{NH}_{4} \mathrm{OH}(14.8)$ \\
\hline T9 & 20 & 0 & 25 & 3 & 1 & 0 and 0 & 5 & 0.1 & 33 & 5.5 & $\mathrm{NH}_{4} \mathrm{OH}(14.8)$ \\
\hline T10 & 20 & 0 & 0 & 3 & 1 & $\begin{array}{c}0.234 \text { and } \\
0.745\end{array}$ & 1 & 0.1 & 37 & 6.0 & $\mathrm{NaOH}(8.75)$ \\
\hline T11 & 50 & 0 & 0 & 0 & 1 & $\begin{array}{c}0.234 \text { and } \\
0.745\end{array}$ & 5 & 0 & 37 & 5.5 & $\mathrm{NH}_{4} \mathrm{OH}(14.8)$ \\
\hline T12 & 20 & 25 & 0 & 0 & 0 & $\begin{array}{c}0.234 \text { and } \\
0.745\end{array}$ & 5 & 0.1 & 33 & 5.5 & $\mathrm{NaOH}(8.75)$ \\
\hline
\end{tabular}


Table S2. Data characterizing L. reuteri DSM 17938 growth and glycerol bioconversion performances

\begin{tabular}{|c|c|c|c|c|c|c|c|}
\hline & $\begin{array}{c}\text { Cell } \\
\text { concentration } \\
\left(\mathrm{g}_{\mathrm{CDW}} \cdot \mathbf{L}^{-1}\right)\end{array}$ & $\begin{array}{c}\text { Top 3-HP titer } \\
\left(\mathrm{g} \cdot \mathbf{L}^{-1}\right)\end{array}$ & $\begin{array}{c}\text { Top 1,3-PDO titer } \\
\left(\mathrm{g} \cdot \mathrm{L}^{-1}\right)\end{array}$ & $\begin{array}{c}\text { Total 3-HP } \\
\text { produced (g) }\end{array}$ & $\begin{array}{c}\text { Total 1,3-PDO } \\
\text { produced (g) }\end{array}$ & $\begin{array}{l}\text { 3-HP production } \\
\text { yield }\left(\mathrm{g}_{3-\mathrm{HP}} \cdot \mathrm{g}_{\mathrm{CDW}}{ }^{-1}\right)\end{array}$ & $\begin{array}{c}\text { Bioconversion } \\
\text { duration (h) }\end{array}$ \\
\hline T1a & 3.4 & 11.2 & 9.4 & 12.4 & 10.4 & 0.76 & 57.7 \\
\hline T1b & 3.0 & 11.9 & 9.0 & 13.7 & 10.4 & 0.90 & 53.4 \\
\hline T1c & 3.6 & 12.3 & 10.0 & 14.1 & 11.5 & 0.68 & 56.2 \\
\hline $\mathbf{T 2}$ & 3.0 & 10.9 & 10.0 & 12.4 & 11.3 & 0.60 & 51.4 \\
\hline $\mathbf{T 3}$ & 4.8 & 9.9 & 10.4 & 11.1 & 11.6 & 0.42 & 52.2 \\
\hline $\mathrm{T} 4$ & 3.2 & 11.0 & 10.0 & 13.3 & 12.1 & 0.88 & 63.2 \\
\hline T5 & 5.1 & 13.9 & 14.0 & 18.9 & 19.0 & 0.61 & 92.3 \\
\hline T6 & 5.7 & 12.7 & 12.8 & 16.1 & 16.1 & 0.50 & 75.6 \\
\hline $\mathbf{T} 7$ & 4.5 & 9.9 & 11.3 & 11.9 & 13.5 & 0.35 & 64.3 \\
\hline T8 & 3.0 & 14.7 & 10.9 & 19.6 & 15.7 & 1.99 & 88.6 \\
\hline T9 & 4.5 & 11.7 & 10.8 & 14.3 & 13.2 & 0.68 & 58.8 \\
\hline T10 & 2.4 & 10.1 & 8.0 & 11.0 & 8.7 & 0.83 & 44.1 \\
\hline T11 & 3.8 & 12.9 & 12.7 & 16.3 & 16.0 & 0.63 & 72.7 \\
\hline T12 & 3.5 & 9.8 & 9.2 & 11.1 & 10.4 & 0.68 & 50.1 \\
\hline
\end{tabular}

